Metallophysics and Advanced Technologies

металофіз. новітні технол.

Metallofiz. Noveishie Tekhnol.

2019 , vol. 41 , No. 4 , pp. $481-500$

https://doi.org/10.15407/mfint.41.04.0481

Reprints available directly from the publisher

PHYSICS OF STRENGTH AND PLASTICITY

PACS numbers: 81.05.Bx, 81.05.Ni, 81.07.Wx, 81.20.Wk, 81.40.Pq, 81.70.Bt

\title{
A Comprehensive Study of Aluminium Based Metal Matrix Composite Reinforced with Hybrid Nanoparticles
}

\author{
R. Venkatesh, Vaddi Seshagiri Rao*, and Sathish Rengarajan* \\ Sathyabama Institute of Science and Technology, Research Scholar, \\ Jeppiaar Nagar, Rajiv Gandhi Road, 600119 Chennai, India \\ "St. Joseph's College of Engineering, \\ OMR, 600119 Chennai, India
}

In this experimental investigation, the mechanical and machinability behaviour of aluminium matrix reinforced with hybrid nanocomposites are studied, considering their widespread application specifically in structural support systems. Aluminium alloy, copper (metal), Alumina (ceramic), and Graphite (an allotropic form of carbon) are chosen for the development of composites, and they justify the term hybrid. They are mixed in the proportion of $\mathrm{Al} 6061-70 \%, \mathrm{Al}_{2} \mathrm{O}_{3}-12 \%, \mathrm{Cu}-9 \%, \mathrm{Gr}-9 \%$ by weight percentage and process by mechanical alloying method, resulting with an average particle size of $70 \mathrm{~nm}$. The SEM and XRD analysis confirm that the materials enter into the nanoregime. Plate- and rod-like shapes are prepare with these composite materials by stir casting process at $500^{\circ} \mathrm{C}$ with rotational speed of $300 \mathrm{rpm}$. The maximum ultimate strength of $156 \mathrm{MPa}$ and hardness of 431.4 $\mathrm{MPa}(44 \mathrm{HV})$ are achieved in the hybrid nanocomposites. The wire cut process assisted by electrical discharge machining is used to assess the machinability aspects of the material. The Taguchi methods of multi-objective optimization are successfully done. Analysis of variance is done to arrive at the correlation coefficient. Minor investigation is also done in order to understand the wear resistance of the material developed. The wear rate of $0.54 \cdot 10^{-10} \mathrm{~m}^{2} / \mathrm{kg}$ is observed at normal loading condition.

Key words: nanopowders, ceramics, metals and alloys, mechanical testing, machining, wear.

Corresponding author: R. Venkatesh

E-mail: venkateshrj73@gmail.com

Citation: R. Venkatesh, Vaddi Seshagiri Rao, and Sathish Rengarajan,

A Comprehensive Study of Aluminium Based Metal Matrix Composite Reinforced with Hybrid Nanoparticles, Metallofiz. Noveishie Tekhnol., 41, No. 4: 481-500 (2019), DOI: $10.15407 /$ mfint.41.04.0481. 
У даному експериментальному дослідженні вивчено поведінку при механо-обробці алюмінієвої матриці, зміцненої гібридними нанокомпозитами, з урахуванням їх широкого застосування, зокрема, в системах опорних конструкцій. Алюмінієвий сплав, мідь (метал), окис алюмінію (кераміка) і графіт (алотропна форма вуглецю) були обрані для розробки композитів, вони виправдовують термін «гібридний». Ці матеріали було змішано в пропорції Al6061 - 70\%, $\mathrm{Al}_{2} \mathrm{O}_{3}-12 \%, \mathrm{Cu}-9 \%, \mathrm{Gr}-9 \%$ за масою та оброблено методом механічного легування, в результаті чого середній розмір часток склав 70 нм. Методами скануючої електронної мікроскопії та рентгенівської дифрактометрії підтверджено, що матеріали перейшли в наностан. Пластини та стрижні, схожі за формою, були виготовлені з цих композиційних матеріалів методом лиття з перемішуванням при температурі $500^{\circ} \mathrm{C}$ та швидкості обертання 300 об/хв. В гібридних нанокомпозитах було досягнуто максимальних значень граничної міцності у 156 МПа та твердості у 431,4 MПа $(44 \mathrm{HV})$. Для оцінки оброблюваності матеріалу було використано процес різання дроту шляхом електроерозійної обробки. Для багатокритеріальної оптимізації було використано метод Тагучі. Для одержання коефіцієнту кореляції здійснено дисперсійний аналіз. Невелике дослідження було також проведено, щоб зрозуміти особливості зносостійкості розроблюваного матеріалу. За нормальних умов навантаження спостерігалася швидкість зношування у $0,54 \cdot 10^{-10} \mathrm{M}^{2} / \mathrm{\kappa г}$.

Ключові слова: нанопорошки, кераміка, метали і сплави, механічні випробування, механічна обробка, зношування.

В данном экспериментальном исследовании изучено поведение при механообработке алюминиевой матрицы, усиленной гибридными нанокомпозитами, с учётом их широкого применения, в частности, в системах опорных конструкций. Алюминиевый сплав, медь (металл), окись алюминия (керамика) и графит (аллотропная форма углерода) были выбраны для разработки композитов, они оправдывают термин «гибридный». Эти материалы были смешаны в пропорции $\mathrm{Al6061}-70 \%, \mathrm{Al}_{2} \mathrm{O}_{3}-12 \%, \mathrm{Cu}-$ 9\%, $\mathrm{Gr}-9 \%$ по массе и обработаны методом механического легирования, в результате чего средний размер частиц составил 70 нм. Методами сканирующей электронной микроскопии и рентгеновской дифрактометрии подтверждено, что материалы перешли в наносостояние. Пластины и стержни, похожие по форме, были изготовлены из этих композиционных материалов методом литья с перемешиванием при температуре $500^{\circ} \mathrm{C}$ и скорости вращения 300 об/мин. В гибридных нанокомпозитах были достигнуты максимальные значения предельной прочности в 156 МПа и твёрдости в 431,4 MПа (44 HV). Для оценки обрабатываемости материала было использовано процесс резки проволоки путём электроэрозионной обработки. Для многокритериальной оптимизации был использован метод Тагучи. Для получения коэффициента корреляции осуществлен дисперсионный анализ. Небольшое исследование было также проведено, чтобы понять особенности износостойкости разрабатываемого материала. При нормальных условиях нагрузки наблюдалась скорость износа в $0,54 \cdot 10^{-10} \mathrm{M}^{2} / \kappa \Gamma$.

Ключевые слова: нанопорошки, керамика, металлы и сплавы, механиче- 
ские испытания, механическая обработка, износ.

(Received November 15, 2018; in final version, January 28, 2019)

\section{INTRODUCTION}

In recent years, the development of hybrid metal matrix composites attracts the researchers, for their various applications. Development of these materials is aimed to enhance the performances of the products. With alumina, silicon carbide, graphite etc. as reinforcements into matrix materials provides novel materials with unique characteristics [1]. Owing to the superior properties like specific strength, specific stiffness, thermal resistance and low coefficient of thermal expansion, these materials are used in different engineering applications [2-4]. Powder metallurgy process was used to develop $\mathrm{B}_{4} \mathrm{C}$ reinforced in different aluminium matrix and studied its mechanical properties. Comparisons were made on aluminium metal matrix composites at $5 \%$ of nano- $\mathrm{Al}_{2} \mathrm{O}_{3}$ by equal channel angular pressing and extrusion process.

Wear behaviour of Al7075 as a base matrix with the addition of $\mathrm{Al}_{2} \mathrm{O}_{3}$ and graphite was investigated and the mechanical properties such as hardness, flexural strength and compression strength were increased by increasing the weight percentage of ceramic phase [5]. Better mechanical properties were achieved when aluminium was reinforced with ceramic particles compared to the unreinforced aluminium alloys [6-8]. It is identified that $\mathrm{SiC}$ can increase wear resistance [911]. Wear resistance is higher and surface roughness is lower for hybrid metal matrix composites when compared to metal matrix composites [12]. Increased tensile strength, compressive strength and hardness were obtained by increasing the weight fraction of FA up to $15 \%$ in $\mathrm{Al}$ (6061) based composites in the work done [11]. AluminiumSilicon alloys were used in brake rotors in Lotus Elise, the Chrysler Prowler and the General Motors EV-1 also in railway application. Though these products are manufactured by sand casting technique there were problems due to settling of silicon carbide particles. To avoid this issue several researchers developed the hybrid composites including graphite particles in aluminium matrix, because it shows improved strength, wear behaviour and also low density due to the presence of graphite particles [12].

Even though most of the researchers concentrate on wear, surface roughness etc., work related to enhancing the properties like tensile strength and hardness along with machining on the nanocomposites in WEDEM are scanty $[13,14]$. In this investigation, deals with manufacturing of powder hybrid nanocomposites into a solid hybrid nanocomposites and testing on mechanical properties and its machinability 
of the samples were studied [15]. This investigation deals with manufacturing of powder hybrid nanocomposites into a solid hybrid nanocomposite structures and testing them for their mechanical properties and machinability aspects, in line with [16] and [17]. Nano composites comprise of $\mathrm{Al}-12 \mathrm{Si}-\mathrm{ZrC}$ with $0,5,10,15 \%$ wt. was mixed by ball milling process the cylindrical component was prepared and tribological study was conducted. Vikas Pare et al. [18] inspire the researchers to develop metal matrix composites with enhanced mechanical properties, to optimize their machinability and to develop an algorithm for the aspiring researchers. The combination of $\mathrm{Al} / \mathrm{SiC} / \mathrm{Gr}$ hybrid composites was reviewed with different proportions and by different casting techniques.

\section{EXPERIMENTAL METHOD}

To prepare a solid material made of hybrid composites, Al6061 was selected as the base metal. The reinforcement materials were of hybrid nanocomposites at the proportion by weight of $12 \% \mathrm{Al}_{2} \mathrm{O}_{3}, 9 \% \mathrm{Cu}$ and $9 \%$ of $\mathrm{Gr}$. The remaining $70 \%$ of the composition is dominated by the base material Al6061. Before the stir casting technique to be adopted, the mechanical alloying technique (Ball milling) was used to reduce the size of microsized Alumina, Copper and Graphite particles, through the planetary motion, in to the nanoregime. To attain this tungsten carbide coated balls were used based on the powder to ball ratio of 10:1. Individually all the alloying elements were milled for 12 hours and all the particles put together for 8 hours. The rotational speed was selected as $350 \mathrm{rpm}$. The hybrid mixture had reached the regime after several hours of milling. The hybrid powders, a mixture of aluminium, copper, alumina and graphite particles were characterized by Quanta-200 Scanning Electron Microscope which ascertained that the particles are under the nanoregime. The composite of hybrid nature with the constituents (reinforcement by nanoparticles) $\mathrm{Al}_{2} \mathrm{O}_{3}, \mathrm{Cu}$, and $\mathrm{Gr}$ were preheated at $500^{\circ} \mathrm{C}$ in graphite crucible, for an easy flow of reinforcement into aluminium matrix. Lighter graphite particles have a property neutralized buoyancy effect on the alumina particles. The hybrid composite material was finally produced by stir casting process. In this liquid metallurgy technique, base metal ingots of weight $700 \mathrm{~g}$ were melted in a furnace at a temperature of $1000^{\circ} \mathrm{C}$, the preheated mixture was mixed by stirring with molten aluminium and poured it in a die. Plate and rod like structures were cast using this stir casting method.

Mechanical characterizations like hardness and tensile strength were determined subsequently. The tensile testing machine of Instron (5900 series) make with a force capacity of $600 \mathrm{kN}$ was used to measure the ultimate tensile strength. Test components were prepared as per ASTM Standards for tensile testing (specimen length $=200 \mathrm{~mm}$, diam- 
eter $=20 \mathrm{~mm}$, gauge length $=60 \mathrm{~mm}$, and diameter of the gauge length zone $=12.5 \mathrm{~mm}$ ). The hardness of the specimen was estimated using Welson Wolpert Vickers hardness testing machine with a measuring range of $200 \mu \mathrm{m}$ at a resolution of $0.01 \mu \mathrm{m}$.

Wear analysis was done using the pin on disk apparatus made by Innovative instruments of POD_ME Blue/RAL 7305 model. The ASTME standard G99 was adopted for the analysis. The composite material thus developed was machined in to pins of circular cross section with the standard size prescribed by G99 of ASTM standards, $70 \mathrm{~mm}$ in length and $7 \mathrm{~mm}$ in diameter so as to fit in the apparatus. EN31 high carbon steel was chosen as disc material, it was machined to the diameter of about $60 \mathrm{~mm}$ and thickness of about $10 \mathrm{~mm}$.

Machinability analysis was done on the plate like structure with a dimension of $100 \times 100 \times 10 \mathrm{~mm}^{3}$ using wire-cut technique based on the electrical discharge machining (EDM). SODICK EX 21(4530D) was the EDM machine used for this experimentation pertaining to machinability. The input parameters chosen for machining were pulse duration, pulse on, pulse off and servo feed. The performance measures were the material removal rate (MRR), Surface roughness and kerf width. Taguchi's L27 Orthogonal array was chosen for the experimental design. The experiments were conducted and multi-response objective on the parameters were studied and optimized using the mathematical concept ANOVA with the aid of Minitab software.

\section{RESULTS AND DISCUSSIONS}

\subsection{Scanning Electron Microscopy}

The SEM analysis was made after milling for $8 \mathrm{~h}$. The morphologies of the observed particles lie in the range between $72 \mathrm{~nm}$ and $113 \mathrm{~nm}$. After $12 \mathrm{~h}$ of milling, it ranges between $76 \mathrm{~nm}$ and $113 \mathrm{~nm}$ at $25000 \mathrm{x}$ magnification. The nanoparticles appear to be randomly scattered. Since there was a time delay in obtaining the SEM results it is understood that the particles got agglomerated.

The hard ceramic materials got disintegrated and easily reached the nanoregime, while the ductile reinforcement copper and the lubricate substance graphite were relatively reluctant to breakdown to enter in to the regime of $10^{-9}$ scale due to the demand for the excessive energy required for plastic deformation. From the SEM images for two different time periods, it is observed that by increasing the milling time, the composite powder containing coarse alumina, gets heavily agglomerated into large particles due to increase in the average size of particles as a result of welding of flattened particles. The images were clear with the reduction in the quantity of Graphite. Figures 1, $a$ and $b$ show the homogeneous distribution of particles in the sample taken. 
The composite powders with coarse reinforcement were more prone to adhere into a larger one, which suggests an excessive cold welding. By subsequent milling for up to 12 hours causes the reduction in particle size where finer particles become dominant. It is noticed that reinforcement particles are well dispersed inside the matrix after long hours of milling. José Manuel Mendoza-Duarte et al. [15] clarifies the similar morphological changes occurred to the reinforcements except for alumina after $8 \mathrm{~h}$ of milling whereas the $4 \mathrm{~h}$ milling does not show any noticeable difference.

\subsection{X-Ray Diffraction Techniques (XRD)}

The samples from each material were taken for XRD study to estimate the crystallite size of the powder, phase constituents, lattice strain. The crystallite size and lattice strain was calculated using the formula [10]:

$$
B \cos \theta=\frac{0.9 \lambda}{d}+\varepsilon \sin \theta,
$$

where $\lambda$ is the wavelength of $\mathrm{Cu} K \alpha$ radiation in $\mathrm{nm}, d$ is the crystallite size in $\mathrm{nm}, \theta$ is the Bragg angle, $\varepsilon$ is the lattice strain and $B$ is the full width at half maximum of the intensity distribution in X-ray diffraction. The XRD tests were conducted individually to all the elements to

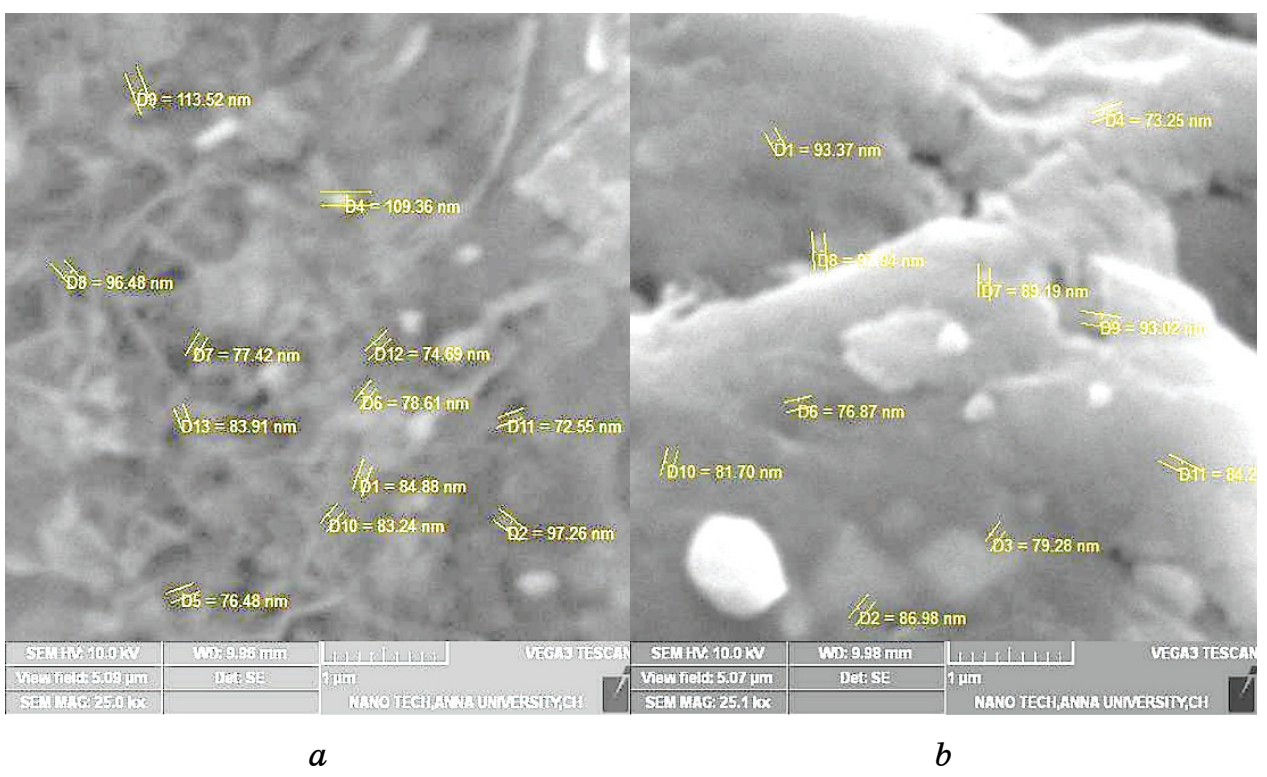

Fig. 1. SEM images after $8(a)$ and $12(b)$ hours of milling. 
ascertain their entry into the nanoregime. The XRD pattern for $\mathrm{Al}_{2} \mathrm{O}_{3}$, $\mathrm{Cu}$, and graphite were shown in the Fig. 2, $a-c$.

From the output results obtained through the X-ray diffraction studies were used with the help of the data base provided by Interna-
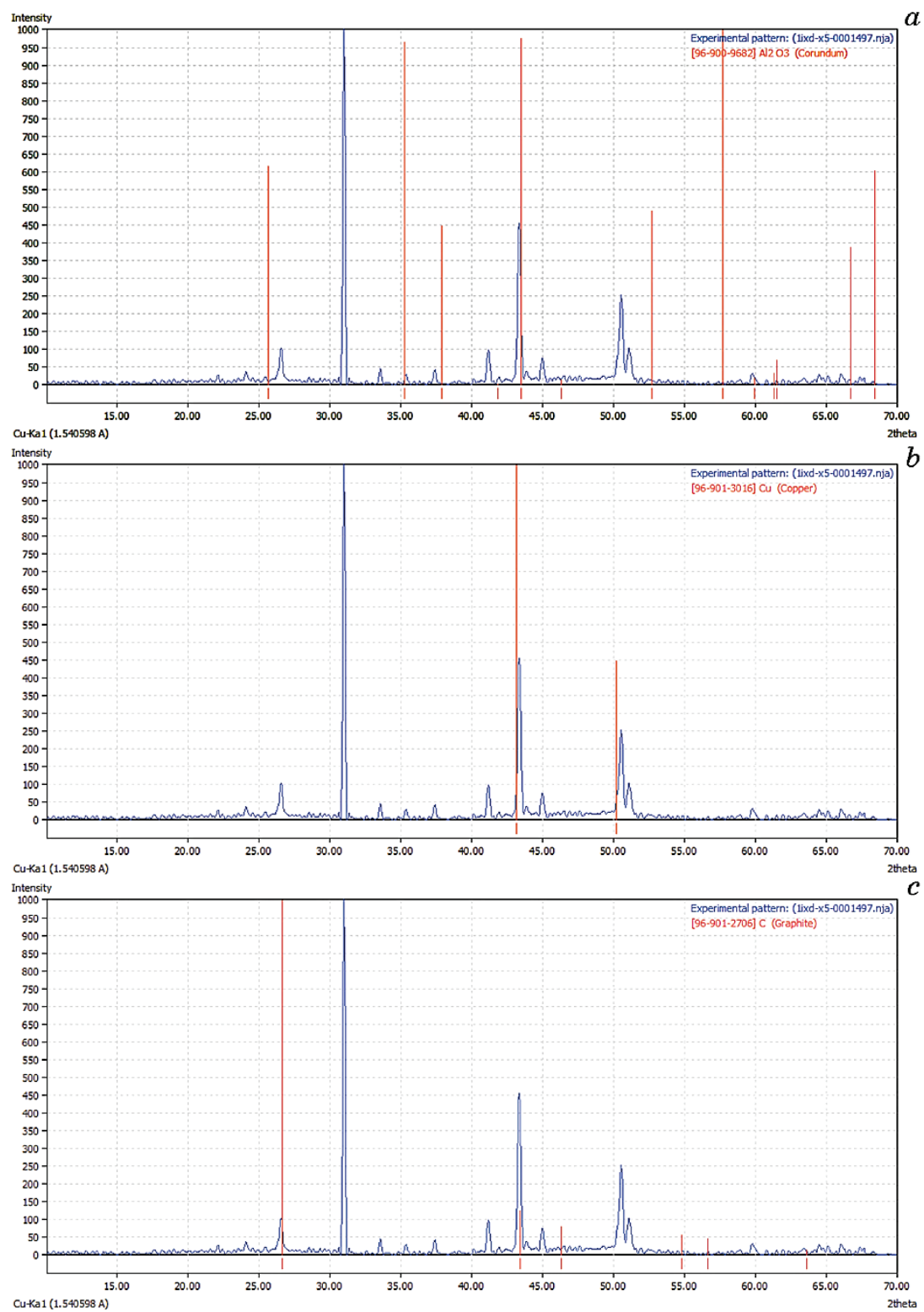

Fig. 2. XRD patterns of $\mathrm{Al}_{2} \mathrm{O}_{3}(a), \mathrm{Cu}(b)$ and graphite $(c)$ powders after reducing them into nanoscale. 
TABLE 1. Crystalline size and strain of the constituent elements in the hybrid.

\begin{tabular}{c|cccc}
\hline Sample No. & Materials & Crystalline size $(\mathrm{m})$ & Strain \\
\hline 1 & $\mathrm{Al}_{2} \mathrm{O}_{3}$ & $3.3088 \cdot 10^{-8}$ & $6.52 \cdot 10^{-4}$ \\
2 & $\mathrm{Cu}$ & $3.2104 \cdot 10^{-8}$ & $3.87 \cdot 10^{-4}$ \\
3 & $\mathrm{Gr}$ & $2.9039 \cdot 10^{-8}$ & $7.42 \cdot 10^{-4}$ \\
\hline
\end{tabular}

tional Council for Powder Diffraction Studies (ICPDS) and supported by material report analyser software, the peak values of all the constituent elements were compared with the values available in the data base and confirmed the presence of all the constituent elements. With the same results morphology and the lattice crystal structure of the constituent elements at the nanoscale were studied. Substituting the values for the parameters in the Scherrer equation the particle size reaching the nanoregime has been confirmed in Table 1 .

The phase $\left(\mathrm{Al}_{2} \mathrm{O}_{3}\right)$ is identified with the patterns with high peak values of $2 \theta=(35,44,53,58)$ at the planes $(104),(113),(024)$, and $(116)$ respectively, which appears similar to the work carried out by Fernando Sánchez de la Torre. The $2 \theta$ value for copper at $44.95^{\circ}$ gives the maximum peak value in plane (111) similarly graphite gains the maximum value at $2 \theta=26.52^{\circ}$ with the plane (002). Similar studies [15] reveal the diffraction of graphite with peak of $2 \theta=25^{\circ}$ the same peak was obtained in the graphite powder. The crystalline size and strain of the constituent elements in the hybrid are shown in Table 1.

\subsection{Mechanical Properties}

The tensile strength of aluminium and hybrid metal matrix composites was shown in Table 2, in which high tensile strength is achieved by the hybrid metal matrix composites. The presence of copper and graphite enhanced the hardness and tensile strength of the hybrid composites. These properties elevate the wear resistance and lubricating tendency of the hybrids developed. The ability of these materials to get ma-

TABLE 2. Comparative results of the mechanical properties.

\begin{tabular}{c|c|c}
\hline Mechanical Property & $\begin{array}{c}\text { Aluminium standard } \\
\text { value }\end{array}$ & $\begin{array}{c}\text { Hybrid composite } \\
\text { developed }\end{array}$ \\
\hline Vickers hardness, $(\mathrm{MPa})$ & $294-323$ & 431.4 \\
Yield strength $\left(\mathrm{kN} / \mathrm{mm}^{2}\right)$ & 52 & 67 \\
Ultimate tensile strength $(\mathrm{MPa})$ & $110-124$ & 156 \\
\hline
\end{tabular}


chined had to be analysed. An appropriate machining was selected and estimated the developed materials ability to undergo better material removal and the quality of surface finish.

The ultimate strength of the aluminium from standards is found to be $124 \mathrm{MPa}$. This value is compared with the ultimate strength of the developed composite material. The graph developed through the data acquisition system of the UTM machine gives the stress $v s$ strain curve, the ultimate strength of the composite material obtained is $\mathbf{1 5 6}$ $\mathrm{MPa}$, which is higher than the strength of aluminium. Figure 3 depicts the tensile test result of the developed composite. The hardness values kept increasing with the increase in the base metal. It is obvious that with the increase in reinforcements, known for their higher hardness, the hardness of the composite should increase. The result shows the adverse effect of the hybrid inclusion. The reason for the unexpected change in hardness is that the constituent elements should find a bonding among themselves. Thus a better mechanical property has been achieved in the new hybrid metal matrix composite.

\subsection{Wear Analysis}

A pilot study was also done on the developed composite materials to investigate its wear resistance using the pin on disc apparatus, after analysing it for the machinability aspects. The load and time details of the pin on disc are shown in Table 3. The coefficient of friction and wear rate were calculated as per the standards [19] and [22]. The track diameter was maintained at $35 \mathrm{~mm}, 45 \mathrm{~mm}$ and $55 \mathrm{~mm}$ respectively for the chosen load and time combinations. Table 3 shows the summarized observations taken through the data acquisition system for the loads of

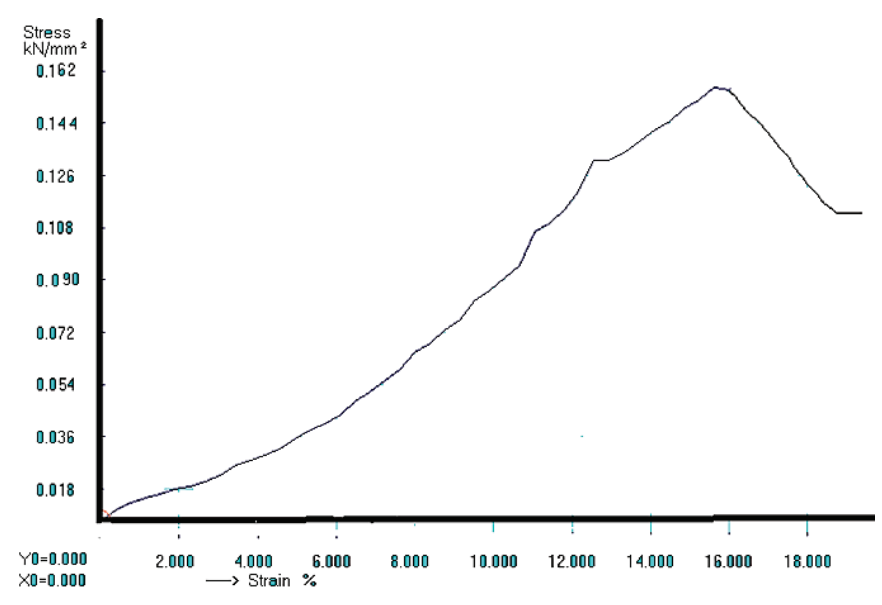

Fig. 3. Stress $v s$ strain curve. 
TABLE 3. Experimental observations.

\begin{tabular}{cccc}
\hline Time $(\min )$ & Load $(\mathrm{N})$ & Coefficient of friction & Friction force $(\mathrm{N})$ \\
\hline 3 & 40 & 0.329 & 13.167 \\
6 & 30 & 0.424 & 9.859 \\
9 & 20 & 0.410 & 4.516 \\
\hline
\end{tabular}

$40 \mathrm{~kg}, 30 \mathrm{~kg}$ and $20 \mathrm{~kg}$ applied for time durations of $3 \mathrm{~min}, 6 \mathrm{~min}$ and 9 min respectively. The coefficient of friction and frictional forces were directly taken from it in real time. The mass of the pin was calculated before and after the test.

The wear rate of the material $=($ differences in mass of the pin before and after the test) $/($ density $\times$ load $\times$ sliding velocity $)$.

The wear rate analysis has clearly been given in Table 4 .

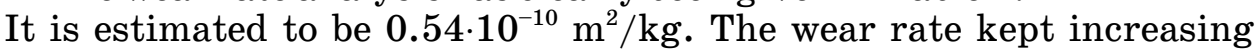
gradually with the increase in the applied load. There is an appreciable resistance to wear at lower loads; the presence of nanoreinforcements resists the wear along with the combination of lubricating substance in graphite and the ductile copper under heterogeneous state. Figure 4, $a$ shows that there is a lower wear rate at low loads, as the applied load increases there is a steep resistance to wear. The increase in sliding distances does not support the wear phenomenon. The rate of wear shows only a meagre change with the increase in the sliding distances, as shown in Fig. 4, $b$. It is understood from the characteristic curves that there is not so much resistance to wear initially over the surface of the workpiece, but due to ageing when the particles settle down in the bulk material, they offer resistances [20] and [21]. This particular behaviour of the composite material restricts the machinists to minimize the depth of cut in conventional machining [22] and [23]. The investigation on the wear resisting capability can be done comprehensively on the developed material. More the material offers resistance to wear

TABLE 4. Wear rate analysis.

\begin{tabular}{c|c|c|c|c|c|c|c|c}
\hline $\begin{array}{c}\text { Track } \\
\text { No. }\end{array}$ & $\begin{array}{c}\text { Track } \\
\text { Diameter } \\
\mathrm{mm}\end{array}$ & $\begin{array}{c}\text { Load, } \\
\mathrm{N}\end{array}$ & $\begin{array}{c}\text { Speed, } \\
\mathrm{rpm}\end{array}$ & $\begin{array}{c}\text { Time, } \\
\text { min }\end{array}$ & $\begin{array}{c}\text { Mass of the pin, } \mathrm{r} \\
\text { Before } \\
\text { the test }\end{array}$ & $\begin{array}{c}\text { After } \\
\text { the test }\end{array}$ & $\begin{array}{c}\text { Sliding } \\
\text { distance, } \\
\mathrm{m}\end{array}$ & $\begin{array}{c}\text { Wear } \\
\text { rate, } \\
\times 10^{-10} \\
\mathrm{~m}^{2} / \mathrm{kg}\end{array}$ \\
\hline 01 & 10 & 20 & 300 & 3 & 5.371 & 5.367 & 28.6 & 0.268 \\
02 & 15 & 30 & 300 & 6 & 5.367 & 5.216 & 84.6 & 0.339 \\
03 & 20 & 40 & 300 & 9 & 5.216 & 5.168 & 169.64 & 0.540 \\
\hline
\end{tabular}




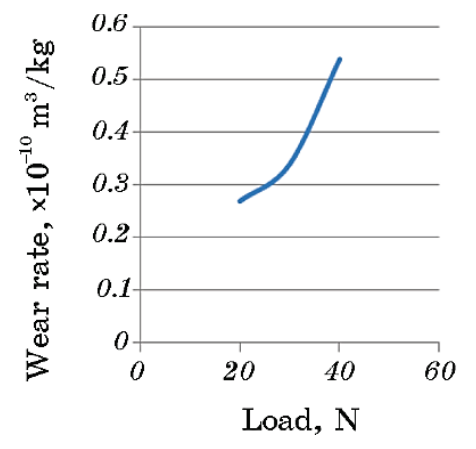

$a$

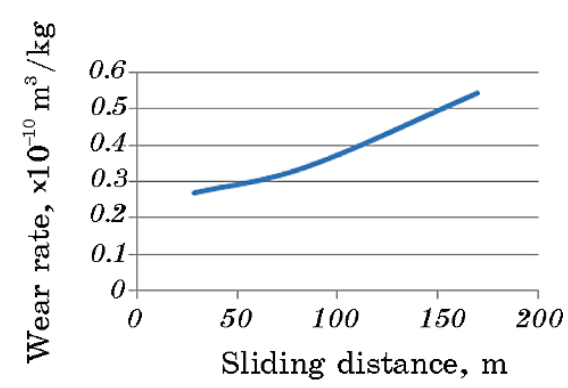

$b$

Fig. 4. Wear rate $v s$. load (a) and sliding distance (b).

more it would be for its machinability using conventional techniques. Such situations prompt the investigators to adopt the unconventional techniques [24] and [25].

\section{MACHINABILITY ANALYSIS}

The raw material with the composition discussed earlier in the previous heading was stir cast in to a plate of dimension $100 \times 100 \times 10 \mathrm{~mm}^{3}$ and machined in wire cut electrical discharge machining. The parameters $T_{\text {on }}, T_{\text {off }}$, wire feed, voltage were chosen as inputs during the machining and further to optimize the input process parameters. A lay out containing the input parameters at three different levels are as shown in Table 5, were chosen so as to accommodate 27 experiments. A time dependent loss in weight of the material up on machining (MRR), the waviness of the surface $\left(R_{a}\right)$ and gap created by the spark produced while machining called kerf width were selected as the measure of results to proceed with the technique of optimization. The experiments were conducted and the observed results were shown in the Table 6 of the orthogonal array $L_{27}$ [20], [21], [26], and [27]. Material removal rate was calculated using the formula

TABLE 5. Input parameters and their levels with ranges.

\begin{tabular}{c|c|c|c}
\hline Input parameters & Level 1 & Level 2 & Level 3 \\
\hline Pulse on $(\mu \mathrm{s})$ & 1 & 3 & 5 \\
Pulse off $(\mu \mathrm{s})$ & 6 & 8 & 10 \\
Wire feed $(\mathrm{m} / \mathrm{min})$ & 6 & 8 & 10 \\
Voltage $(\mathrm{V})$ & 50 & 55 & 60 \\
\hline
\end{tabular}


MRR $=$ mean cutting speed $\times$ thickness of the material in $\mathrm{mm} \times$ $\times$ width of $\operatorname{cut}(\mathrm{mm})=V c t b \mathrm{~mm}^{3} / \mathrm{min}$.

The MRR gives the flexibility to represent it in terms of $\mathrm{kg} / \mathrm{min}$, the weight of the material was measured before and after the machining,

TABLE 6. Experimental observations.

\begin{tabular}{c|c|c|c|c|c|c|c|c}
\hline $\begin{array}{c}\text { Sample } \\
\text { No. }\end{array}$ & $T_{\text {on }}$ & $T_{\text {off }}$ & $\begin{array}{c}\text { Wire } \\
\text { feed }\end{array}$ & Voltage & $\begin{array}{c}\text { Time taken } \\
\text { to machine }\end{array}$ & $\begin{array}{c}\text { Kerf } \\
\text { width }\end{array}$ & $R_{a}$ & MRR \\
\hline Units & $\mu \mathrm{s}$ & $\mu \mathrm{s}$ & $\mathrm{m} / \mathrm{min}$ & $\mathrm{V}$ & $\mathrm{min}$ & $\mathrm{mm}$ & $\mu \mathrm{m}$ & $\mathrm{kg} / \mathrm{min}$ \\
\hline 1 & 1 & 6 & 6 & 50 & 9.03 & 0.321 & 3.46 & 0.0459 \\
2 & 1 & 6 & 8 & 55 & 8.98 & 0.319 & 3.49 & 0.0456 \\
3 & 1 & 6 & 10 & 60 & 8.97 & 0.323 & 3.51 & 0.0461 \\
4 & 1 & 8 & 8 & 50 & 8.95 & 0.322 & 3.48 & 0.0455 \\
5 & 1 & 8 & 10 & 55 & 8.90 & 0.325 & 3.49 & 0.0459 \\
6 & 1 & 8 & 6 & 60 & 9.07 & 0.321 & 3.43 & 0.0457 \\
7 & 1 & 10 & 10 & 50 & 8.85 & 0.319 & 3.48 & 0.0453 \\
8 & 1 & 10 & 6 & 55 & 9.11 & 0.316 & 3.35 & 0.0449 \\
9 & 1 & 10 & 8 & 60 & 9.05 & 0.319 & 3.44 & 0.0450 \\
10 & 3 & 6 & 6 & 50 & 9.19 & 0.321 & 3.34 & 0.0444 \\
11 & 3 & 6 & 8 & 55 & 9.10 & 0.319 & 3.32 & 0.0441 \\
12 & 3 & 6 & 10 & 60 & 8.99 & 0.323 & 3.30 & 0.0446 \\
13 & 3 & 8 & 8 & 50 & 9.02 & 0.323 & 3.33 & 0.0443 \\
14 & 3 & 8 & 10 & 55 & 8.97 & 0.331 & 3.28 & 0.0449 \\
15 & 3 & 8 & 6 & 60 & 9.15 & 0.324 & 3.39 & 0.0450 \\
16 & 3 & 10 & 10 & 50 & 8.99 & 0.326 & 3.31 & 0.0446 \\
17 & 3 & 10 & 6 & 55 & 9.12 & 0.323 & 3.33 & 0.0448 \\
18 & 3 & 10 & 8 & 60 & 9.05 & 0.318 & 3.30 & 0.0441 \\
19 & 5 & 6 & 6 & 50 & 9.01 & 0.323 & 3.34 & 0.0439 \\
20 & 5 & 6 & 8 & 55 & 8.83 & 0.326 & 3.38 & 0.0441 \\
21 & 5 & 6 & 10 & 60 & 8.77 & 0.325 & 3.32 & 0.0444 \\
22 & 5 & 8 & 8 & 50 & 8.85 & 0.320 & 3.37 & 0.0440 \\
23 & 5 & 8 & 10 & 55 & 8.78 & 0.318 & 3.35 & 0.0443 \\
24 & 5 & 8 & 6 & 60 & 8.99 & 0.321 & 3.46 & 0.0444 \\
25 & 5 & 10 & 10 & 50 & 8.79 & 0.326 & 3.38 & 0.0443 \\
26 & 5 & 10 & 6 & 55 & 8.98 & 0.323 & 3.49 & 0.0439 \\
27 & 5 & 10 & 8 & 60 & 8.93 & 0.320 & 3.47 & 0.0441 \\
\hline & & & & & & & & \\
\hline
\end{tabular}


the difference in their weight divided by the machining time also gives the MRR in terms of weight, whereas the formula given above is the MRR in terms of volume loss. The other two parameters namely kerf width and Surface roughness have been tested using the sophisticated measuring devices a video measuring device and a surface roughness tester of INSPEX make respectively.

\subsubsection{Kerf Width Analysis}

Kerf width is one the most important performance measures in WEDM. Kerf width is the gauging factor that weighs the amount of the material that is wasted during machining. Closeness of the machined part, in terms of dimensions, to the designed value has been determined by the kerf width analysis. The gap between the two parallel and opposite surfaces of the work piece usually lies in between $\mathbf{0 . 0 2 5}$ and $0.075 \mathrm{~mm}$. This gap is being constantly held by a computer interfaced positioning system.

Figure 5 summarises the role of control process variables in maximizing the process responses (minimizing a signal-to-noise (SN) ratios). It is evident from the Figure that the points A3, B2, C3 and D4 are the significant control parameters to keep the expected loss function of 'smaller the better' intact and the optimal value derived from the regression equation is $0.382 \mathrm{~mm}$.

Regression equation for kerf width was arrived using the mini tab software which is given in the following equation.

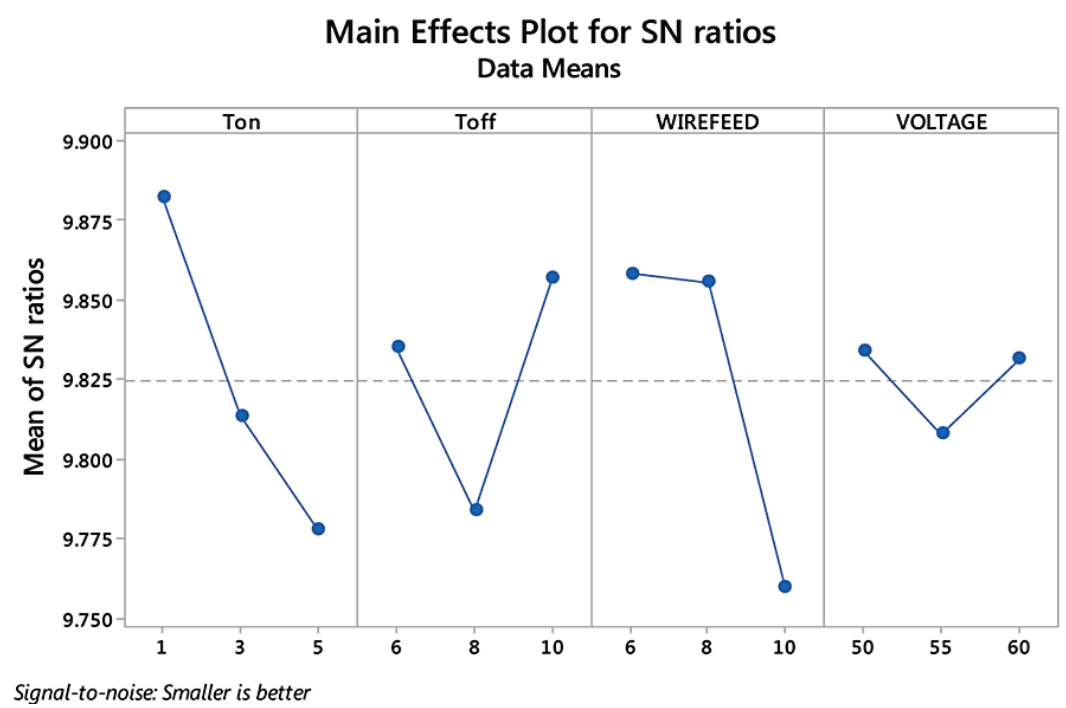

Fig. 5. Kerf width. 
TABLE 7. ANOVA for kerf width.

\begin{tabular}{c|c|c|c|c|c|c}
\hline Source & $\begin{array}{c}\text { Degrees } \\
\text { of free- } \\
\text { dom (DF) }\end{array}$ & $\begin{array}{c}\text { Adjusted } \\
\text { Sum of } \\
\text { Squares (SS) }\end{array}$ & $\begin{array}{c}\text { Adjusted } \\
\text { Mean Squa- } \\
\text { re (MS) }\end{array}$ & $\begin{array}{c}\text { F- } \\
\text { Value }\end{array}$ & P-Value & Significance \\
\hline Regression & 4 & 0.000066 & 0.000016 & 1.53 & 0.228 & \\
$T_{\text {on }}$ & 1 & 0.000035 & 0.000035 & 3.23 & 0.086 & \\
$T_{\text {off }}$ & 1 & 0.000002 & 0.000002 & 0.14 & $0.710>$ F & Significant \\
Wire feed & 1 & 0.000029 & 0.000029 & 2.66 & 0.117 & \\
Voltage & 1 & 0.000000 & 0.000000 & 0.01 & $0.911>$ F & Significant \\
Error & 22 & 0.000236 & 0.000011 & & & \\
Total & 26 & 0.00302 & & & & \\
\hline
\end{tabular}

Kerf width $=0.31539+0.000694 T_{\text {on }}-0.000147 T_{\text {off }}+$

+0.000631 wire feed +0.000018 voltage

From the analysis of variance as shown in Table 7, it is observed that the $T_{\text {off }}$ and voltage are the significant values in attaining the optimum kerf width. The normal probability plot as given in Fig. 6 shows that all the experimental values are much closer to the trend line, no abnormal
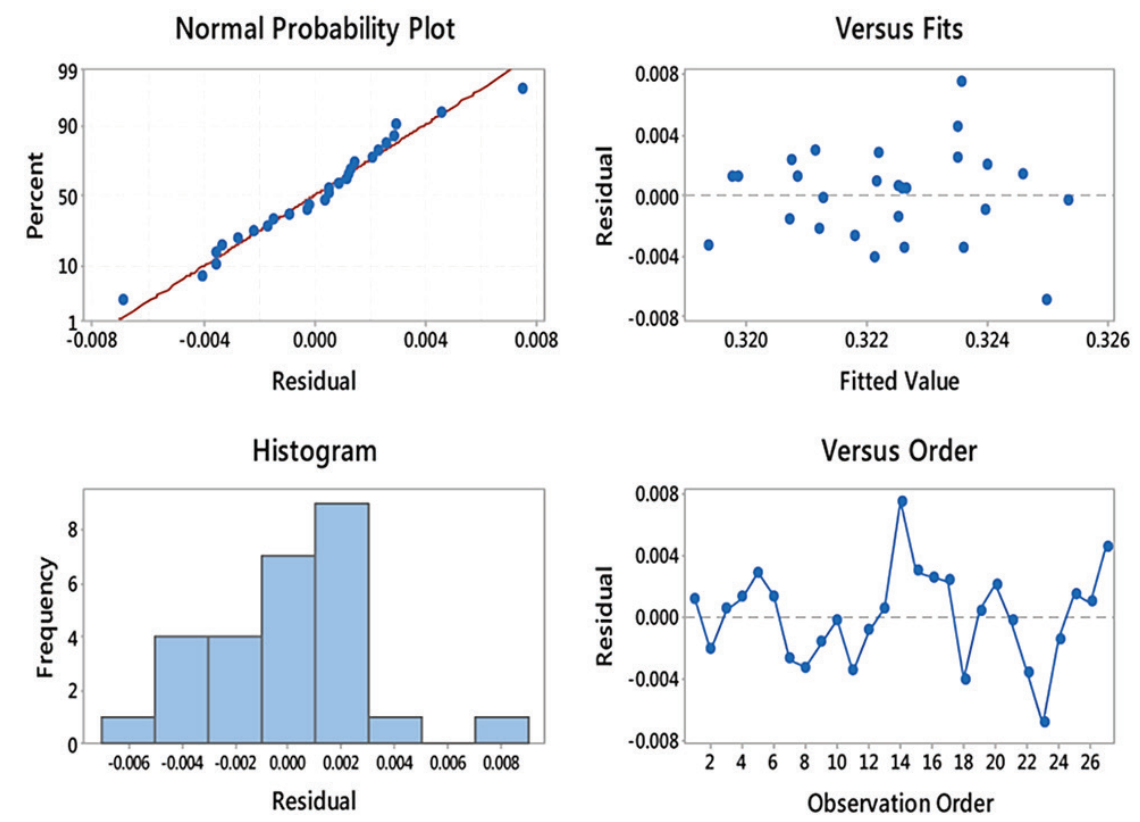

Fig. 6. Residual plots for kerf width. 
deviation is found in any of the experiments other than the last one. The correlation between the experiment and the model lies at $82.75 \%$.

\subsubsection{Surface Roughness Analysis}

The surface roughness is an important factor that is considered while machining. With the raise in the current and pulse on duration, Surface roughness also tends to increase at every level. This is due to the effect of spark that leads to larger crater and thus a rough surface is obtained. It is observed that surface roughness increased with peak current at constant voltage. At higher value of current the surface degradation initially increases with voltage. With further increase in voltage, the surface roughness reduces. Surface roughness values are important in precision equipment where the mating points should not have any gap in between to provide a satisfactory performance in the long run. The plot of SN ratios as shown in Fig. 7 pertaining to surface roughness to determine the significant parameters that play a crucial role in ascertaining the loss function 'smaller the better'. Higher smoothness is the expectation of any machining. In this case the values at A3, B2, C2 and D3 are the significant contributions to attain an optimum surface roughness. The regression equation is given below:

$$
\begin{gathered}
\text { Surface roughness } R_{a}=3.355-0.01556 T_{\text {on }}+0.00626 T_{\text {off }}- \\
-0.00437 \text { wire feed }+0.00128 \text { voltage }
\end{gathered}
$$

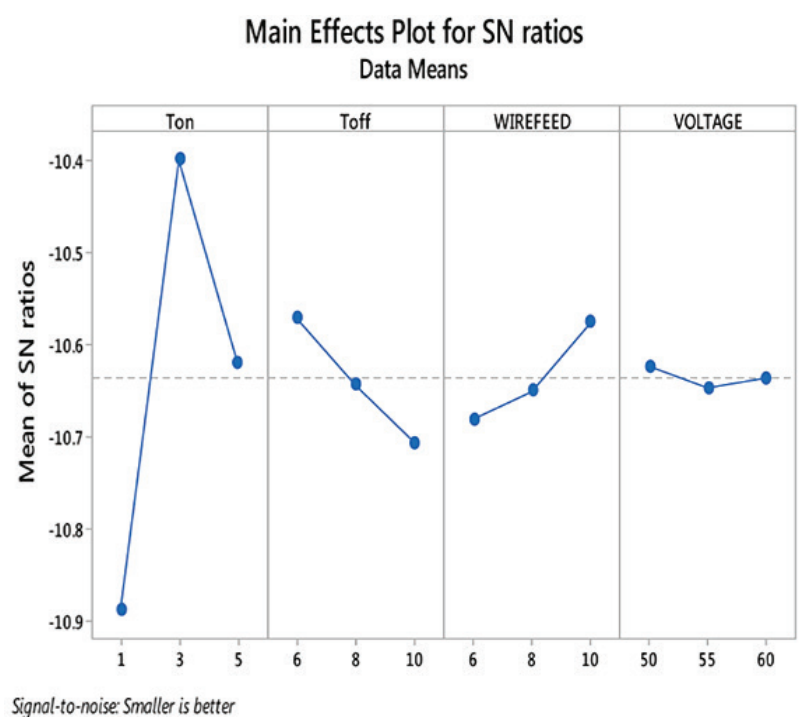

Fig. 7. Surface roughness. 
TABLE 8. ANOVA for surface roughness.

\begin{tabular}{ccccccc}
\hline Source & DF & Adj SS & Adj MS & F-Value & P-Value & Significance \\
\hline Regression & 4 & 0.022875 & 0.00571 & 1.05 & 0.405 & \\
$T_{\text {on }}$ & 1 & 0.017422 & 0.017422 & 3.19 & 0.088 & \\
$T_{\text {off }}$ & 1 & 0.002759 & 0.002759 & 0.51 & 0.485 & \\
Wire feed & 1 & 0.001373 & 0.001373 & 0.25 & 0.621 & Significant \\
Voltage & 1 & 0.000725 & 0.000725 & 0.13 & 0.719 & Significant \\
Error & 22 & 0.120043 & 0.005457 & & & \\
Total & 26 & 0.142919 & & & & \\
\hline
\end{tabular}

The optimal value of the $R_{a}$ model has been arrived at $3.3923 \mu \mathrm{m}$.

Table 8 for the analysis of variations pertaining to surface roughness clearly indicates that the wire feed and the voltage play a significant role to keep the surface roughness under considerably low level. The Normal probability plot as presented in the Fig. 8 states that the error is linear and under the predicted levels. The initial experiments slightly goes away from the mean on the positive side where as the final few experiments falls short of the mean on the other way around. The correlation of the model $R^{2}$ is $70.73 \%$.
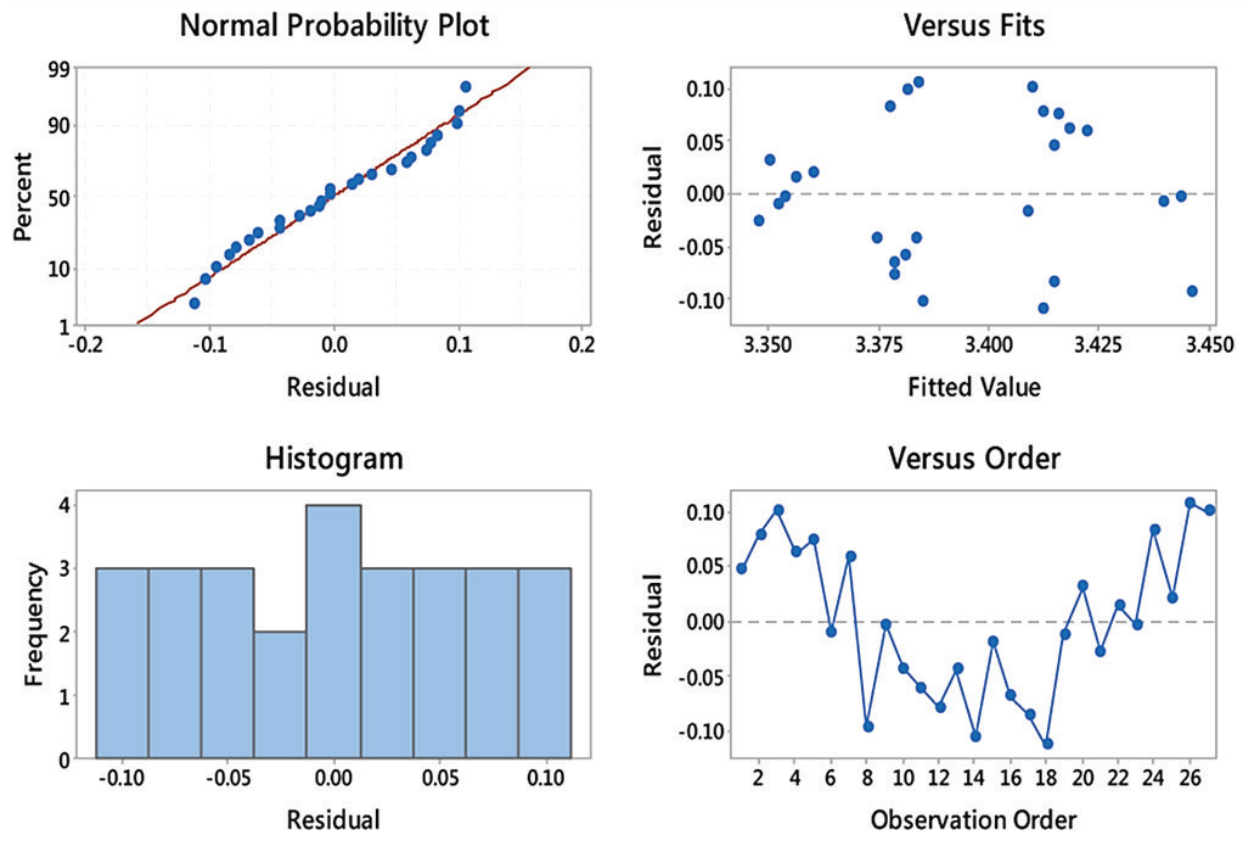

Fig. 8. Residual plots for $R_{a}$. 


\subsubsection{Analysis on the Material Removal Rate}

The material removal rate (MRR) of the work piece is the amount of the material removed per minute. MRR and cutting speed capabilities of WEDM have increased enormously over the years. They are influenced by the age and type of machine along with the properties and characteristics of the work piece being cut. The machine settings set by the operator and programmer also affect the MRR and cutting speed.

From the Fig. 9, it is understood that A1, B2, C3 and D2 are the process parameters that are significant in getting the optimum value of material removal. The design value of MRR is estimated to be 0.049 $\mathrm{kg} / \mathrm{min}$. The regression equation of MRR is given as

$$
\begin{aligned}
& \mathrm{MRR}=0.04524-0.000347 T_{\text {on }}-0.000056 T_{\text {off }}+ \\
& +0.000052 \text { wire feed }+0.000010 \text { voltage }
\end{aligned}
$$

From the Table 9, it has been observed that the input parameter voltage alone is considered as the significant contributing factor to increase the MRR. The normal probability plot which is shown in Fig. 10 gives a linear relation between the experimental values and the model for MRR and there isn't any deviation from the mean line. The reason for an increased MRR is the voltage. More the potential difference is maintained, the amount of material removed under unit time is also more.

The $R^{2}$ value obtained says that $72.95 \%$ of the values are correlated. The loss function of the MRR is always 'higher the better'. From the

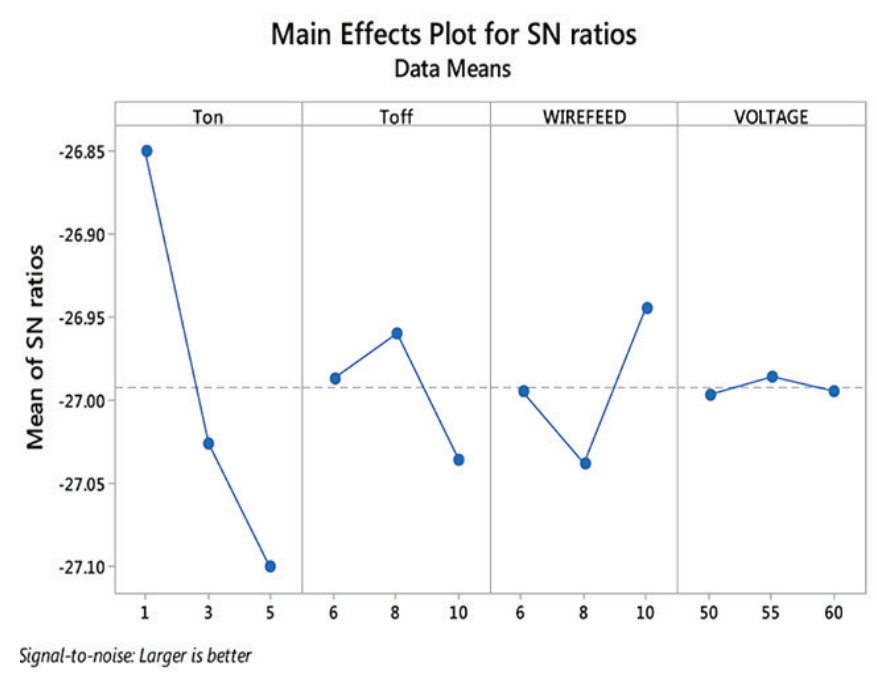

Fig. 9. Material removal rate. 
TABLE 9. ANOVA for MRR.

\begin{tabular}{c|c|c|c|c|c|c}
\hline Source & DF & Adj SS & Adj MS & F-Value & P-Value & Significance \\
\hline Regression & 4 & 0.000009 & 0.000002 & 14.83 & 0.00 & \\
$T_{\text {on }}$ & 1 & 0.000009 & 0.000009 & 56.27 & 0.00 & \\
$T_{\text {off }}$ & 1 & 0.000000 & 0.000000 & 1.44 & 0.242 & \\
Wire feed & 1 & 0.000000 & 0.000000 & 1.28 & 0.270 & \\
Voltage & 1 & 0.000000 & 0.000000 & 0.30 & 0.587 & Significant \\
Error & 22 & 0.000003 & 0.000000 & & & \\
Total & 26 & 0.000013 & & & & \\
\hline
\end{tabular}
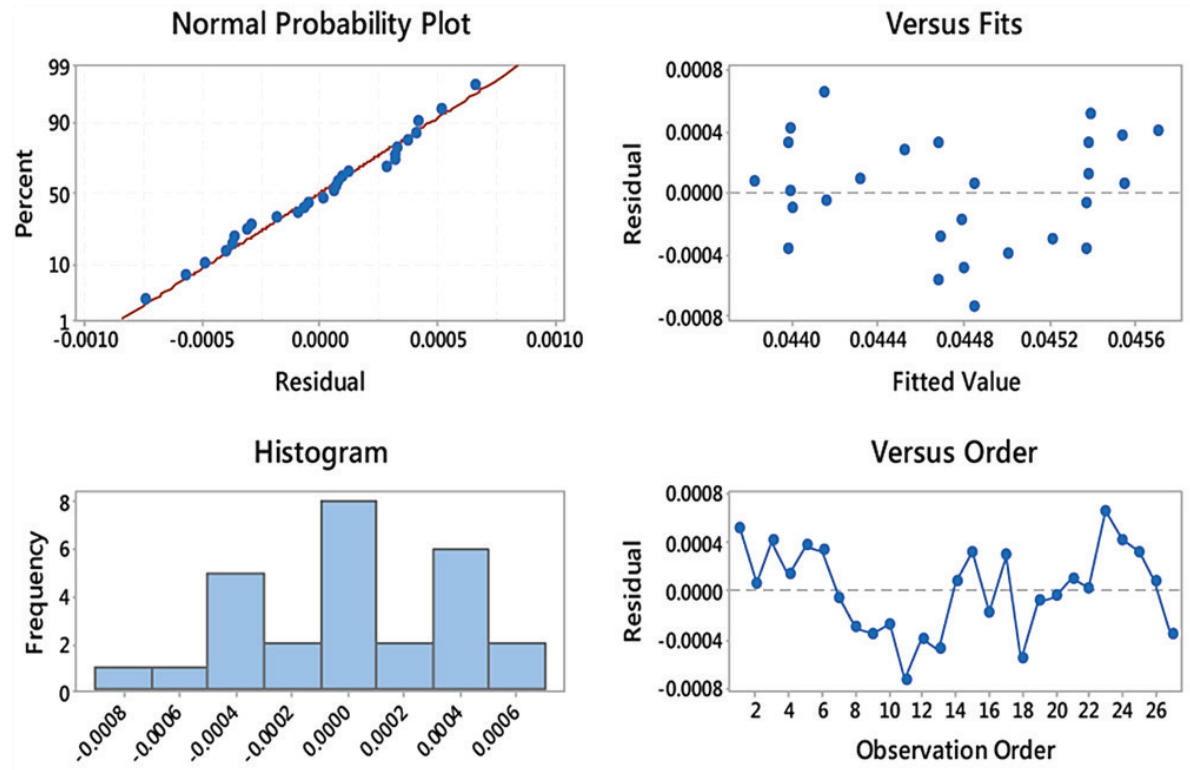

Residual

Fig. 10. Residual plots for MRR.

regression equation of $\mathrm{MRR}$, the optimal is estimated as 0.0493 $\mathrm{kg} / \mathrm{min}$.

\section{CONCLUSION}

A unique hybrid combination of two metals, a ceramic and an allotropic form of carbon, was developed with a combination of $70 \% \mathrm{Al}-$ $12 \% \mathrm{Al}_{2} \mathrm{O}_{3}-9 \% \mathrm{Cu}-9 \% \mathrm{Gr}$ at nanoscale. Homogeneous distribution of reinforcements in the composite powder with smaller particle size was achieved by mechanical alloying method. The particles show an aver- 
age size of $72.55 \mathrm{~nm}$. The stir cast composite posses the tensile strength and hardness as $156 \mathrm{~N} / \mathrm{mm}^{2}$ and $44 \mathrm{HV}$ respectively. Machinability analysis was done to optimize using Taguchi method. Increase of Pulse on time generates more spark energy as the length of time of electricity supply increases. MRR, kerf width and surface roughness, all these responses increase with pulse on time. Pulse on time found most significant parameter in all response. Surface roughness also increases with increase of pulse on time because the increases of pulse on time produce crater with broader and deeper characteristic. Pulse off time has opposite effect to pulse on time. MRR decrease with increase of pulse off time, while surface roughness reduces. During off time removed material flushed away. More the off time better the flushing. Wire feed, current and wire material has the least effect when compared to the pulse on time and pulse off time. The wear resistance of the material under normal load was observed as $0.54 \cdot 10^{-10} \mathrm{~m}^{2} / \mathrm{kg}$.

\section{REFERENCES}

1. G. M. Owolabi, A. G. Odeshi, M. N. K. Singh, and M. N. Bassim, Mater. Sci. Eng. A, 457: 114 (2007).

2. D. S. Prasad and C. Shoba, J. Mater. Res. Tech., 3, Iss. 2: 172 (2014).

3. K. K. Alaneme and M. O. Bodunrin, J. Miner. Mater. Char.Eng., 10 (12): 1153 (2011).

4. $\quad$ M. Kok, J. Mater. Process. Tech., 161 (3): 381 (2005).

5. R. D. Haghighi, S. A. J. Jahromi, and A. Moresedgh, J. Mater. Eng. Perform., 21: 1885 (2012).

6. A. Baradeswaran and A. Elaya Perumal, Composite Part B: Engineering, 56: 464 (2014).

7. Akhtar S. Khan, Babak Farrokh, and Laszlo Takacs, Mater. Sci. Eng. A, 489: 77 (2008).

8. M. O. Vasyliev, B. M. Mordyuk, S. I. Sidorenko, S. M. Voloshko, A. P. Burmak, and M. V. Kindrachuk, Metallofiz. Noveishie Tekhnol., 38, No. 4: 545 (2016).

9. N. Raghumatham, E. K. Loannidis, and T. Sheppard, J. Mater. Sci., 26: 985 (1991).

10. Y. N. Liang and Z. Y. Ma, J.Mater.Sci. Lett., 1: 114 (1995).

11. N. Ch. Kaushik and R. N. Rao, Tribol. Int., 103: 298 (2016).

12. B. N. Mordyuk, G. I. Prokopenko, Yu. V. Milman, M. O. Iefimov, E. Grinkevych, A. V. Sameljuk, and I. V. Tkachenko, Wear, 319: 84 (2014).

13. E. Gikunoo, O. Omotoso, and I. N. A. Oguocha, Mater. Sci. Tech., 21 (2): 143-52 (2005).

14. Sanjeev Garg, Alakesh Manna, and Ajai Jain, Arab J.Sci.Eng., 38: 3471 (2013).

15. Mendoza-Duarte José Manuel, Estrada-Guel Ivanovich, Robles-Hernandez Francisco Carlos, Carreño-Gallardo Caleb, López-Meléndez Claudia, and Martínez-Sánchez Roberto, Mat. Res., 19, Suppl. 1: 13 (2016).

16. Sanjeev Kumar Garg and Alakesh Manna, J. Eng. Res., 1, No. 1: 213 (2013).

17. S.K. Garg, A. Manna, and A. Jain, J Braz.Soc. Mech.Sci.Eng., 38: 481 
(2016).

18. Vikas Pare, J.Mech.Eng., 61, No. 3: 176 (2015).

19. B. Stojanovic, M. Babic, S. Mitrovic, A. Vencl, N. Miloradovic, and M. Pantic, J. Balkan Tribol. Assoc., 19, No. 1: 83 (2013).

20. N. E. Arun Kumar and A. Suresh Babu, Mater. Manuf. Processes, 33, No. 1: 85 (2017).

21. N. E. Arun Kumar, A. Suresh Babu, and D. Murali, International Journal of Chemical Sciences, Published by Sadguru Publications, Vol. 14, Iss. 2: 1051 (2016).

22. R. Venkatesh and V. S. Rao, Defence Tech., 14: 346 (2018).

23. D. Jeyasimman, Mater. Des., 64: 783 (2014).

24. Ratna Deepika and Manikonda Satyanarayana, Mater. Today Proc., 5, Iss. 9, Part 3: 20104 (2018).

25. S. Baskaran and V. Anandakrishnan, Mater. Today Proc., 5, Iss. 6: 14273 (2018).

26. Inderdeep Singh, Sarbjit Singh, and Abhishek Singh, Mach. Mach. Tool., Research and Development Woodhead Publishing Reviews: Mechanical Engineering Series: 169 (2013).

27. A. Pramanik, International J. Mach. Tool. Manufacture, 86, November: 44 (2014). 